- дать импульс повышению интереса к региону и его изучению.

Атлас как автономный и сетевой продукт может служить каналом связи между различными целевыми группами пользователей атласа.

Учебно-краеведческий электронный атлас Саратовской области - произведение нового поколения, воплощающее в себе современные технологии и большой массив географических знаний, сохраняющее преемственность с известными образцами отечественной картографической продукции. Как целостное произведение атлас может стать информационно-справочной системой, содержащей различную информацию о регионе, которая благодаря сети Интернет может быть доступна большому числу пользователей.

\section{Библиографический список}

1. Сваткова Т.Г. Атласная картография. М., 2002. 203 с.

2. Паршина Ю.В. Структура и содержание учебного электронного географического атласа Саратовской области // ИнтерКарто/ИнтерГИС 14: Устойчивое развитие территорий: теория ГИС и практический опыт: Материалы Междунар. конф., Саратов, Урумчи - 2008. Саратов, 2008. C. 262-265.

3. Демин А.М., Макариева Л.В., Уставщикова С.В. География Саратовской области. Саратов, 2008. 336 с.

4. Берлянт А.М., Востокова А.В., Кравиова В.И. и др. Картоведение. М., 2003. 477 с.

5. Берлянт A.M. Картография: Учебник для вузов. M., 2002. $336 \mathrm{c}$.

УДК [581.526.53:630*182.4] (470.44)

\title{
ДРЕВЕСНО-КУСТАРНИКОВАЯ РАСТИТЕЛЬНОСТЬ КАК ЭЛЕМЕНТ ЛАНДШАФТОВ ПОЛУПУСТЫННОГО САРАТОВСКОГО ПРИУЗЕНЬЯ
}

\section{Н.В. Пичугина}

Саратовский государственный университет, кафедра физической географии и ландшафтной экологии E-mail: geogr@sgu.ru

Статья посвящена анализу места древесно-кустарниковой растительности природного и антропогенного происхождения в структуре и функционировании ландшафтов полупустынного Саратовского Приузенья. В работе использованы материалы полевых исследований разных лет, топографические и тематические карты, космические снимки, элементы ГИС-технологий.

Ключевые слова: ландшафты, полупустыня, Саратовская область, Заволжье, древесно-кустарниковая растительность.

Tree-shrubbery Vegetation as the Element of Landscapes of semi-desert Saratov Priuzenye

\section{N.V. Pichugina}

This article is devoted to the analyses of the role of tree-shrubbery vegetation of natural and anthropogene origin in the structure and functioning of landscapes of semi-desert Saratov Priuzenye. In this work there are used the materials of field field researches of different years, topographic and subject charts, space photographs, elements of GIS-technologies.

Key words: landscapes, semi-desert, Saratov Region, Zavolzhye, tree-shrubbery vegetation.

Ассоциативно северная полупустыня Прикаспийской низменности воспринимается как плоская безлесная равнина с однообразным внешним обликом. Вместе с тем более близкое знакомство с исследуемой территорией открывает интересные и эффектные элементы ее ландшафтной структуры, одним из которых является древеснокустарниковая растительность.

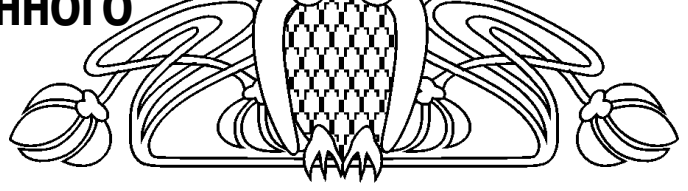

Целью представленной работы являются рассмотрение состава древесно-кустарниковой растительности природного и антропогенного происхождения, анализ ее роли в функционировании геосистем. Для исследования выбрана территория полупустынного Саратовского Приузенья.

Исходные материалы и источники. В рамках данной работы были использованы: материалы полевых исследований 1990, 1992, 1997 , 1998, 2004, 2007 и 2009 гг., топографические и тематические (почвенные, ландшафтные и др.) карты, космические снимки, научные публикации (монографии, статьи).

Методы исследования: описательный, сравнительный, картографический с использованием геоинформационных технологий. Для определения местоположения в полевых условиях применялся GPS-приемник.

Исследуемая территория административно охватывает юго-западную часть Новоузенского района (около 25\% от площади района) и $97 \%$ Александрово-Гайского района Саратовской области.

Со второй половины XX в. к вопросу физикогеографического районирования Саратовского Заволжья обращались многие исследователи: П.С. Кузнецов [1], Н.К. Алексеевская и М.А. Шабанов [2], А.К. Пестряков и др. [3, 4], А.Г. Доскач [5], И.В. Копыл [6] и В.А. Николаев [6, 7], В.3. Макаров и др. [8, 9], Н.В. Пичугина [10] и др.

Неизменным на схемах ландшафтного районирования было выделение на крайнем юге левобережья Саратовской области полупустынной зоны. В пределах Волго-Уральского междуречья 
она приурочена к северной части Прикаспийской низменности. Вместе с тем следует отметить, что до сих пор существуют разночтения в определении названия и зональной принадлежности полупустыни у ландшафтоведов, геоботаников и почвоведов. Например, в работе Г.М. Абдурахманова, Д.А. Криволуцкого и др. [11] лесостепь и полупустыня относятся в качестве подзон, соответственно, к «луговым степям» и «опустыненным степям» степной зоны. И.Н. Сафронова [12] также определяет северную полупустыню как «опустыненную степь».

В работах В.А. Ковды [13], М.С. Буяновского и др. [14], А.Г. Исаченко [15], в монографиях [16-18] северная часть Прикаспийской низменности входит в состав полупустынной зоны. В справочнике-определителе [19] светлокаштановые почвы являются индикатором северной подзоны, а бурые полупустынные почвы - южной подзоны «пустынно-степной» или «полупустынной» зоны. М.А. Глазовская и А.Н. Геннадиев [20] рассматривают полупустыню в качестве самостоятельной природной зоны, а ее зональным типом называют бурые пустынностепные почвы. Вместе с тем они отмечают «тяготение» к полупустыне светло-каштановых почв.

Обзор работ, посвященных вопросам определения границ, ландшафтного ранга и названия полупустынной зоны, можно продолжить. Как отмечает В.А. Николаев [7], с 1907 г. в географии используется термин «полупустыня» для обозначения зонального экотона между степными и пустынными ландшафтами. Термин «опустыненная степь», используемый в работах геоботаников [12] и других исследователей, можно рассматривать в качестве уточняющего названия для северной полупустыни.

В пределах Саратовской области северная граница полупустыни идет от р. Малый Узень (южнее с. Августовка) к пос. Алгайский и г. Новоузенск, пересекает р. Большой Узень, затем следует на восток через хут. Морозов к р. Дюра (южнее с. Пограничное).

В соответствии со схемой физико-географического районирования Прикаспийской низменности [6], Приузенская равнина относится к Узенско-Чижинскому физико-географическому району Северо-Волго-Уральской провинции. Согласно ландшафтному районированию Саратовской области [8] и Саратовского Заволжья [9, 10], рассматриваемая территория входит в состав Приузенского (Межузенского) ландшафтного района северной полупустыни Прикаспийской низменности.

На Приузенской равнине представлено четыре зональных ландшафта и два интразональных долинных ландшафта [9, 10]. Между рр. Большой Узень и Малый Узень находятся Межузенские северный и южный ландшафты, а в левобережной части Большого Узеня - Узенско-Дюринский и Узенско-Большелиманский ландшафты. Межузен- ский северный и Узенско-Дюринский ландшафты приурочены к раннехвалынской поверхности Прикаспийской низменности с абсолютными высотами 25-38 м. Межузенский северный ландшафт вытянут с северо-запада на юго-восток на 57 км, a Узенско-Дюринский имеет протяженность с севера на юг около 18 км. Межузенский южный и Узенско-Большелиманский ландшафты находятся на среднехвалынской поверхности Северного Прикаспия и характеризуются высотами 20-25 м над у.м. Их протяженность с северо-запада на юго-восток в пределах Саратовской области составляет около 25 км.

Основными элементами ландшафтной структуры исследуемой территории являются аккумулятивные плоские и слабонаклонные равнины с двучленными и трехчленными пустынностепными комплексами (ПСК), урочища падин и лиманов, а также долинные геосистемы.

Почвенно-растительный покров ландшафтов характеризуется комплексностью. На светло-каштановых почвах представлены белополынно-ковыльно-типчаковые, типчаковые и ромашниково-типчаковые сообщества. К солонцам приурочены прутняково-камфоросмовочернополынные и эфемерово-чернополынные галофитные ассоциации. На лугово-каштановых почвах западин и падин распространены разнотравно-ковылково-тонконоговые, разнотравно-тырсово-мезофитнозлаковые луговые степи в сочетании с зарослями степных кустарников. Для гидроморфных комплексов характерны разнотравно-галофитнозлаковые, галофитнозлаково-селитрянополынно-пырейные, бекманиевые и вейниковые луга на луговых и лугово-лиманных почвах. Местоположения с более близким к поверхности залеганием грунтовых вод занимают осоково-камышовые, тростниково-клубнекамышовые, рогозовые, галофитноразнотравно-ситнягово-пырейные, кермеково-солеросовые сообщества и заболоченные луга на лугово-болотных иловатых почвах и солонцах.

Значительные площади Саратовского Приузенья занимают Малоузенский и Большеузенский долинные ландшафты. Вторые надпойменные террасы со светло-каштановыми остаточнолуговатыми почвами и их комплексами с солонцами здесь плавно переходят в ландшафты междуречных равнин. На лугово-каштановых почвах и аллювиальных слоистых почвах долин встречаются лесные массивы, заросли кустарников, а также злаково-разнотравные и злаковые луга из канареечника, пырея и костра.

Подробная характеристика природных условий и ландшафтной структуры исследуемой территории дана в ранее опубликованных работах $[9,10,21,22$ и др.].

Древесно-кустарниковая растительность природного происхождения в северной полупустыне приурочена к долинам рек, приречным 
балкам и оврагам; заросли кустарников - к западинам и падинам междуречных равнин, лиманным понижениям.

Лесные массивы («культюки») встречаются в основном на первой надпойменной террасе и пойме р. Большой Узень $[23,24]$. Их доля в ландшафтной структуре исследуемого района не превышает $1 \%$. Вместе с тем они имеют большое значение и как места произрастания многих редких для полупустынной зоны видов растений, и как места обитания различных представителей животного мира, и как элементы природного экологического каркаса. Изучение долинных геосистем было проведено в 1997 г. совместно с В.А. Николаевым и И.В. Копыл [21], а также в полевые сезоны 2004 г. [10, 22] и 2007 г. [23, 24]. Древесный ярус культюков в основном формируют тополь белый, вяз гладкий и клен татарский. Во втором ярусе встречаются вяз приземистый (мелколистный), клен американский, ясень пенсильванский (зеленый), внедрение которых в долинные сообщества обусловлено, видимо, их самораспространением из придорожных и полезащитных лесополос. Кустарниковый ярус представляют жимолость татарская, крушина слабительная, роза собачья, роза иглистая и ежевика сизая. Куртины из кустарников образуют терн, таволга городчатая, спирея зверобоелистная, миндаль низкий (бобовник), солодка уральская. Единично или небольшими группами в культюках встречаются яблоня и груша. Ближе к воде появляются ветла и кустарниковая форма ивы. Густые заросли на отдельных участках формирует лох остроплодный (узколистный).

Для балок и оврагов Приузенской равнины характерны, прежде всего, заросли степных кустарников. Здесь встречаются терн, таволга городчатая, спирея зверобоелистная, миндаль низкий (бобовник), солодка уральская, ива (кустарниковая форма), лох узколистный. Заросли кустарников чаще всего приурочены к нижним частям склонов и днищам балок и оврагов, реже к их верховьям.

Следующим элементом ландшафтной структуры северной полупустыни, обеспечивающим благоприятные условия для произрастания степных кустарников, являются падины и западины («степные блюдца»). Они приурочены к междуречным равнинам, где занимают неглубокие понижения со слабо выраженными бортами. Площадь падин может составлять от нескольких до сотни гектаров, а относительная глубина 1-1,5 м. Диаметр западин 5-10 м, иногда - больше, относительная глубина - около 0,5 м. Для этих понижений характерно наличие линзы пресной воды, образующейся за счет перераспределения поверхностного стока, а также формирование лугово-каштановых почв. Западины, как правило, являются составным элементом трехчленных пустынно-степных комплексов. Кустарниковый ярус западин и падин образуют спирея зверобоелистная и бобовник. Иногда среди зарослей спиреи встречаются отдельные кусты терна или розы собачьей.

В первой половине XX в. доля пахотных угодий составляла 11-12\% от площади Саратовского Приузенья и была приурочена преимущественно к падинам. Падины использовали для выращивания зерновых и бахчевых культур, а также под яблоневые сады, иногда с участием груши. Кроме этого, они служили сенокосными угодьями. Как отмечают Н.Г. Сенкевич и И.Н. Оловянникова [25], в северной полупустыне Волго-Уральского междуречья из-за выпаса скота, сенокошения и распашки земель значительно сократилась площадь, занятая степными кустарниками. В середине 80-х гг. ХХ в. в совхозах Александрово-Гайского района проводили специальные мероприятия по уничтожению степных кустарников на пастбищах. Больше всего, видимо, от этой борьбы пострадал миндаль низкий. Во время полевых исследований, проводимых совместно с Н.Г. Сенкевич в 1992 г., на рассматриваемой территории к югу от с. Александров Гай была выявлена лишь одна падина с зарослями бобовника. В этой падине в начале XXI в. миндаль низкий обнаружить уже не удалось. Вместе с тем снижение нагрузки на пастбищные угодья в последние два десятилетия привело к восстановлению на отдельных участках Приузенской равнины трехчленных пустынно-степных комплексов. Это проявляется, в частности, в растительном покрове западин, когда происходит восстановление кустарникового элемента. В мае 2009 г. во время полевых исследований к западу от с. Сысоева было выявлено, что формирование кустарникового яруса западин естественным путем происходит не только за счет спиреи зверобоелистной, но и бобовника. Он образует сообщества со спиреей или, иногда, формирует монодоминантные заросли. Заросли кустарников начинают восстанавливаться и на старых залежах.

Еще одним естественным местом произрастания для кустарников являются лиманные понижения с близким залеганием грунтовых вод. Неглубокие лиманы с луговыми и лугово-лиманными почвами и их комплексами с солонцами под пырейными и бекманиевыми сообществами, иногда с зарослями солодки (голой и уральской), используют под сенокосы или выпас скота. Реже встречаются лиманы, которые полностью заняты солодкой. Этот кустарник распространен также на придорожных и приканальных участках. Местные жители используют корень солодки в лекарственных целях, а также в пищу для приготовления моченых яблок, при засолке помидоров, огурцов и арбузов.

В 90-е гг. XX в. и в первое десятилетие XXI в. кустарники начали осваивать новые места. Нередко происходит зарастание кустарниковой формой ивы приканального пространства, а также дна и бортов земляных каналов, периодически заполняемых водой. Аналогичная ситуация складывается и около прудов. В последние два десятилетия 
наметилась тенденция освоения придорожных и приканальных пространств самосевом лоха узколистного и гребенщика (тамарикса). Необходимо отметить, что от дорог и каналов лох активно продвигается и на прилегающие пространства, создавая заросли в виде небольших колков и обозначая, видимо, зону фильтрации пресных вод из каналов и прудов. Тамарикс осваивает земли на месте заброшенных орошаемых участков. Его можно встретить здесь в виде отдельно стоящих кустов или небольших групп.

Древесно-кустарниковая растительность антропогенного происхождения. Доминирующее положение в структуре зеленых насаждений антропогенного происхождения занимают придорожные лесополосы. Для создания лесополос в полупустыне необходимо предварительное проведение мероприятий по мелиорации солонцов и светло-каштановых солонцеватых почв. Нередко эти мероприятия проводились в усеченном виде или игнорировались вовсе. В настоящее время придорожные лесополосы имеют куртинный и мелкоколочный характер. В тех случаях, когда зеленые насаждения попадают на участки падин или западин с лугово-каштановыми почвами, состояние древесно-кустарниковой растительности можно признать удовлетворительным или хорошим. Особенно это характерно для падин. Здесь наблюдается формирование устойчивого природно-антропогенного комплекса. Древеснокустарниковую растительность антропогенного происхождения в придорожных лесополосах чаще всего представляют вяз мелколистный, клен американский, смородина золотая, реже - ясень зеленый и тополь пирамидальный.

Состояние лесополосы, идущей вдоль автомобильной дороги с. Александров Гай - с. Варфоломеевка, на участке от с. Александров Гай до с. Сысоева неудовлетворительное. В древесном ярусе доминирует вяз приземистый. Его высота около 2-3 м. Крона слабо сформирована. На большей части рассматриваемого отрезка вяз погиб или находится в угнетенном состоянии. Иногда встречаются ясень зеленый и клен американский. В кустарниковом ярусе преобладает смородина золотая. На отдельных участках она сочетается с караганой древовидной (желтой акацией). Кустарники находятся в удовлетворительном состоянии.

В нескольких километрах от с. Сысоева на северной стороне дороги находится участок семнадцатирядной лесополосы, исследование которой проводилось в 1992 г. и 2009 году. Участок выделяется относительно хорошим состоянием древесно-кустарникового яруса. Его длина составляет 450 м, ширина - около 57 м, площадь около 2,6 га. Высота деревьев достигает 5-6 м. В центральной части рассматриваемого «лесного острова» кроны деревьев сформировали сомкнутый полог. К границам участка снижается густота насаждений, уменьшается высота деревьев, на открытых пространствах развивается степная и лугово-степная растительность. У противоположной стороны дороги посадки находятся в неудовлетворительном состоянии, хотя несколько лучше, чем на остальном отрезке лесополосы от с. Александров Гай до с. Сысоева.

Анализ топографических карт и космических снимков показал, что «лесной массив» приурочен к обширной падине, которую в ее южной части пересекают дорога и лесополосы. Падина имеет дугообразную форму. Ее ширина варьирует от 180 м в северной части до 450 м на юге. Длина составляет около 2300 м, площадь - около 85 га. Уклон поверхности наблюдается с севера на юг, к дороге. Механический барьер в виде дорожной насыпи высотой 1,5-2 м перекрывает возможности для поступления влаги с поверхностным стоком на участки лесополосы вдоль южной стороны дороги. Уплотнение пород под дорожным полотном, видимо, затрудняет перемещение влаги из линзы пресной воды основной части падины в ее южную часть. Это может в определенной степени объяснить неудовлетворительное состояние лесополосы к югу от дорожного полотна.

Меньшее распространение на Приузенской равнине получили приканальные и полезащитные лесополосы. В основном насаждения этих категорий приурочены к землям Новоузенского района, где вдоль водных каналов иногда высаживают тополь пирамидальный. Целесообразным представляется использование в посадках около прудов и водохранилищ, по берегам рек, в балках и оврагах, вдоль каналов тех видов деревьев и кустарников, которые хорошо чувствуют себя в «культюках» на р. Большой Узень. В состав подобных насаждений могут войти тополь белый, клен татарский, вяз гладкий, лох узколистный; из кустарников - роза собачья, терн, жимолость татарская и др.

Небольшой лесной массив из тополя есть на окраине с. Камышки (около 13 га), из вяза приземистого, ясеня зеленого и клена американского - на западной окраине с. Александров Гай (12 га и 43 га). Аналогичные массивные зеленые насаждения встречаются около других населенных пунктов или в их пределах в виде парков. Около административных зданий, школ и других учреждений в составе древесно-кустарниковой растительности представлены тополь, вяз мелколистный, ясень зеленый, реже - сирень, тамарикс.

К первой надпойменной террасе р. Большой Узень приурочены коллективные сады, которые были разбиты в основном в 50-80-е гг. XX века. Здесь выращивали яблоню, грушу, вишню, терн, сливу, смородину золотую и крыжовник. Полив садов осуществляли из р. Большой Узень. В 90-е гг. сады были заброшены.

С конца 70-х гг. древесно-кустарниковая растительность получила распространение на приусадебных участках сельских жителей, особенно в селах Александров Гай, Новоалександровка и Камышки. Для посадок в палисадах 
наиболее часто использовали вяз мелколистный, тополь, сирень и шиповник. В последние два десятилетия здесь появились береза, сосна и черемуха. Есть положительные примеры по выращиванию рябины обыкновенной, липы мелколистной, дуба черешчатого, акации белой и лещины. В настоящее время обычными представителями садов являются яблоня, груша, вишня, терн, слива, облепиха, смородина и крыжовник. Меньшее распространение имеют черешня, абрикос, боярышник, ирга, малина и калина. Полив плодово-ягодных и декоративных культур в летние месяцы осуществляется из р. Большой Узень.

\section{Выводы}

1. Естественная древесно-кустарниковая растительность является составным элементом геосистем северной полупустыни. В структуре ландшафтов доля этого элемента незначительна. Вместе с тем его наличие в составе комплексов повышает эстетическую привлекательность, устойчивость и разнообразие локальных геосистем, которые являются местом обитания многих представителей животного мира или их временного местонахождения во время миграций. Нарушение древесно-кустарникового элемента может привести к деградации геосистем в целом. Памятники природы, приуроченные к долинным, пустынно-степным и лиманным комплексам, занимают незначительные площади [23, 24]. К сожалению, даже статус охраняемых территорий не всегда гарантирует им полную защищенность от антропогенного воздействия.

2. Использование падин и западин в качестве пахотных угодий, сенокосов и пастбищ привело к нарушению растительных сообществ, в том числе и кустарникового элемента. После снятия антропогенной нагрузки начинается восстановительный процесс, который, однако, занимает значительный отрезок времени. Одним из путей участия человека в этом процессе является перенесение местного посадочного материала спиреи зверобоелистной и бобовника в западины и падины на участках, выведенных из активного хозяйственного использования. Внедрение интродуцентов на этих землях должно быть сведено к минимуму, так как важно, хотя бы в общих чертах, сохранить исходную ландшафтную структуру и своеобразие северной полупустыни. Восстановление кустарникового элемента будет способствовать увеличению запасов пресной воды в линзах западин и падин, создавать благоприятный фон для формирования растительных сообществ окружающих равнин с пустынно-степными комплексами.

3. Защитное лесоразведение на рассматриваемой территории характеризуется малым разнообразием видов деревьев и кустарников, незначительной площадью зеленых насаждений, неэффективной организацией лесоустроительных мероприятий.

Куртинный и мелкоколочный характер придорожных лесополос в Саратовском Приузенье подтверждает выводы, к которым пришли исследователи, изучавшие возможности лесоразведения в северной полупустыне на землях Джаныбекского стационара. Согласно Н.Г. Сенкевич и И.Н. Оловянниковой (1996 г.), наиболее благоприятные условия для выращивания древесных насаждений складываются в больших падинах, менее благоприятные - в западинах. Они отмечают, что создание лесных насаждений на межпадинной равнине с пустынно-степным комплексом требует обязательного проведения предварительной мелиорации солонцов и постоянного ухода за почвой [25].

Следует, видимо, изменить процесс организации придорожных лесополос. На первом этапе по линии планируемой лесополосы необходимо провести посадку древесно-кустарниковой растительности лишь на участках падин и западин. В состав этих насаждений можно включать аборигенные виды деревьев и кустарников, а также интродуценты, хорошо зарекомендовавшие себя в аналогичных условиях северной полупустыни на землях Джаныбекского стационара. Для озеленения и защитного лесоразведения в аридных зонах юго-востока России Н.Г. Сенкевич и И.Н. Оловянникова [25] предлагают использовать 96 видов деревьев и кустарников. Наиболее широкий спектр видов характерен для падин. В кустарниковый ярус западин, наряду со спиреей, розой собачьей и бобовником, могут войти боярышник, бузина, жостер слабительный, скумпия и другие кустарники. Скумпия страдает от сильных морозов, но при этом она хорошо восстанавливается, очень декоративна, мало привлекательна для скота. После формирования устойчивых древеснокустарниковых и кустарниковых сообществ в западинах и небольших «лесных колков» в падинах можно проводить их постепенное «смыкание» посадками на солонцах и светло-каштановых почвах. На «соединительных» участках потребуется предварительная работа по мелиорации солонцов. Подобный подход позволит избежать неэффективных затрат и уйти от высоких потерь посадочного материала из-за его плохой приживаемости на землях пустынно-степного комплекса. Вместе с тем, учитывая недолговечность, низкорослость и плохую сформированность крон у древесных пород, произрастающих на солонцах и светлокаштановых почвах, на этих участках следует увеличить долю кустарникового элемента. В кустарниковый ярус «зон смыкания» можно включить такие виды, как смородина золотая, терн, барбарис обыкновенный, ирга, сирень обыкновенная, карагана древовидная, тамарикс многоветвистый и др. Приоритет стоит отдавать солеустойчивым, засухоустойчивым и морозоустойчивым видам. По окраинам лучше высаживать более устой- 
чивые виды, например терн, лох узколистный и облепиху, которые могут выполнять функцию живых изгородей.

В целом следует отметить, что хрупкая природа северной полупустыни требует адаптированного землепользования, оптимально вписанного в исходную ландшафтную структуру.

\section{Библиографический список}

1. Физико-географические районы Нижнего Поволжья / Под ред. П.С. Кузнецова. Саратов, 1961. 156 с.

2. Алексеевская Н.К., Шабанов М.А. Физическая география Поволжья. Саратов, 1969. 35 с.

3. Алексеевская Н.К., Будигина Л.В., Пестряков А.К. К вопросу построения схемы среднемасштабного районирования степного Заволжья // Вопросы физической географии и геоморфологии Нижнего Поволжья. Саратов, 1975. Вып. 3(7). С. 3-14.

4. Лихт З.Б., Пестряков А.К. К составлению ландшафтной карты Низкого Заволжья //Вопросы истории и теории физической географии. Саратов, 1979. Вып. 5(12). С. 69-88. 5. Доскач А.Г. Природное районирование Прикаспийской полупустыни. М., 1979. 143 с.

6. Копыл И.В., Николаев В.А. Физико-географическое районирование Прикаспийской низменности по материалам космической съемки // Вестн. Моск. ун-та. Сер. 5, Геогр. 1984. № 1. С. 65-70.

7. Николаев В.А. Евразийская полупустыня (к 100-летию открытия полупустынной природной зоны) // Там же. 2007. № 6. C. 3-9.

8. Макаров В.3., Пролеткин И.В., Чумаченко А.Н. Ландшафтная структура Саратовской области: Карта. Масштаб $1: 500000$ // Эколого-ресурсный атлас Саратовской области / Под ред. В.С. Белова. Саратов, 1996. С. 7.

9. Макаров В.3., Пичугина Н.В., Павлова А.Н. Некоторые аспекты методики составления ландшафтных карт разного масштаба (на примере Саратовского Заволжья) // Поволжский экологический журнал. 2008. № 4. С. 293-303. 10. Пичугина Н.В. Ландшафтная структура полупустынного Саратовского Приузенья // Ландшафтоведение: теория, методы, региональные исследования, практика; Материалы XI Междунар. ландшафтной конф., Москва, 22-25 августа, 2006 г. / Отв. ред. К.Н. Дьяконов. М., 2006. C. 230-232.

11. Биогеография: Учебник для студ. вузов / Г.М. Абдурахманов, Д.А. Криволуцкий, Е.Г. Мяло, Г.Н. Огуреева. М., 2003. 480 c.
12. Сафронова И.Н. Современное состояние опустыненных степей Поволжья: прошлое, настоящее, будущее // Биоресурсы и биоразнообразие экосистем Поволжья. Материалы международного совещания. Саратов, 24-28 апреля 2005 г. / Под ред. Д.С. Павлова. Саратов, 2005. С. 96-97.

13. Ковда В.А. Почвы Прикаспийской низменности. М.; Л., $1950.256 \mathrm{c}$.

14. Буяновский М.С., Доскач А.Г., Фридланд В.М. Природа и сельское хозяйство Волго-Уральского междуречья. M., $1956.230 \mathrm{c}$.

15. Исаченко А.Г. Ландшафтоведение и физико-географическое районирование. М., 1991. 366 с.

16. Почвенно-географическое районирование СССР (в связи с сельскохозяйственным использованием земель) / Отв. ред. П.А. Летунов. М., 1962. 423 с.

17. Юго-Восток Европейской части СССР / Ред. И.П. Герасимов. М., 1971. 460 с.

18. География Саратовской области / Под ред. Н.В. Тельтевской. Саратов, 1993. 219 с.

19. Почвы СССР: Справочник-определитель / Т.В. Афанасьева, В.И. Василенко, Т.В. Терешина, Б.В. Шеремет. Отв. ред. Г.В. Добровольский. М.: Мысль, 1979. 380 с.

20. Глазовская М.А., Геннадиев А.Н. География почв с основами почвоведения: Учебник. М., 1995. 400 с.

21. Николаев В.А., Копыл И.В., Пичугина Н.В. Ландшафты полупустынного Саратовского Заволжья и возможности оптимизации их использования // Геоэкология Саратова и области. Саратов, 1999. Вып. 3. С. 27-30.

22. Пичугина Н.В. Приузенская равнина и ее земледельческая освоенность во второй половине ХХ в. // Изв. Сарат. ун-та. Новая серия. 2004. Т. 4. Науки о Земле, вып. 1. C. $133-139$.

23. Пичугина Н.В., Завьялов Е.В. Александрово-Гайские культюки. Леляевская комплексная полупустыня. Лиманы Глубокий, Крутой // Особо охраняемые природные территории Саратовской области: национальный парк, природные микрозаповедники, памятники природы, дендрарий, ботанический сад, особо охраняемые геологические объекты / Комитет охраны окружающей среды и природопользования Саратовской области; Науч. ред. В.3. Макаров. Саратов, 2007. С. 48-54.

24. Пичугина Н.В. Новоузенские культюки // Там же. C. $188-190$.

25. Сенкевич Н.Г., Оловянникова И.Н. Интродукция древесных растений в полупустыне Северного Прикаспия. M., 1996. 184 c. 